\title{
クラス人数規模と保育空間構成に関する研究 \\ 1 歳児クラスの活動場面に着目して \\ A STUDY ON THE CLASS SIZE AND THE NURSERY SPACE COMPOSITION
}

Focusing on the activity scene of one-year-old child class

\author{
長谷川 恵美*1，定行 まり子*2 \\ Megumi HASEGAWA and Mariko SADAYUKI
}

\begin{abstract}
The purpose of this research is to propose a design method of nursery room that suits the group size of 1-year-old class. Observation studies are conducted for 4 facilities to examine how the group size affect the daily program, childcare methods, and usage of space. Then, from the viewpoint of "children's independence", it is preferable to prepare the space they could change place with actions at the transition from lunch to napping when the group size is 20 or more. Furthermore, we found that partitioning off a room gives childminders options to organize the suitable group size for each activity.
\end{abstract}

Keywords : Nursery School, One-year-old infants, Nursery Daily Program, Transition Processes, Group Size 保育所，1歳览，保育スケジュール，活動の移行，集団規模

1. 研究の背景と目的、位置づけ

\section{$1-1$ 研究の背景と目的}

待機児童の問題が長期化する中、近年 3 歳未満児の保育所利用率 が上昇している注1)。これをうけ保育所保育指針 1)注2)の改訂では、3 歳未満児の保育に関する詳細な記述が新たに加わり、3 歳未満児の 保育の重要性が改めて認識されることとなった。また平成 29 年に育 児・介護休業法注 3 ) が改正され、1 歳から保育施設で集団生活に入る 子どもが今後増えることが見込まれ、保育施設における 1 歳児の保 育が着目されると推察される。

一方、全国保育協議会 ${ }^{2)}$ によれば、近年保育施設の定員・現員総 数は共に増加傾向にあり、Fig. 1より、1 施設当たりの 1 歳児の現員 数は、10〜14 人を最多とする一方で、20 人以上の規模が徐々に増加 しつつあり、1 歳児保育の人数規模が大きくなってきていることが

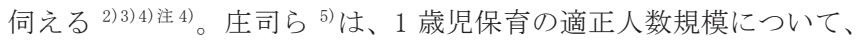
過去の研究事例から 7 13 人と述べ、他の年齢に比べ 1 歳児保育に おいて理想值と現実の乘離が大きいことを指摘している。このこと から 1 歳児保育の人数規模について、適正規模からの乘離が更に進 んでいると言える。また保育所における保育室等の室面積は、園児 一人あたりの面積基準が定められている。このため建築計画時には 認可定員数に比例して、保育室等の室面積は拡大されることになる が、人数規模が倍である場合、単に保育室等を拡大寸るのか、それ とも適正規模といわれる人数単位で空間を区切るのか、現在基準が
存在しない。すなわち子どもが 24 人の場合、12 人の場合の 2 倍の 面積と職員配置数を満たすだけで、それぞれ同等の保育の質が確保 しうるのか明らかにされていない。したがって、本研究では、近年 保育需要が高まる 1 歳児クラスを対象に、保育の流れ、各活動場面 における行為と空間の使われ方、子どもと保育者の様子について“子 どもの主体的な活動を大切にした環境” 1) という視点から分析し、 クラス人数規模と空間構成のあり方について考察し、設計指針を得 ることを目的とする。なお、“子どもの主体的な活動を大切にした環 境” 1) という視点とは、後述するが、3 歳未満児期は身の回りのこ とが自分でできるようになっていく時期であり、着替えや食事など の基本的な生活行為を自分でしようとする子どもの気持ちを尊重し、 受け入れやすい環境であるか、ということである。

\section{1-2 既往研究との位置づけ}

日本建築学会論文報告集において、保育所における 3 歳未満児を 対象とした、保育方法と空間構成に関する既往研究には、小川ら ${ }^{67)}$ による保育プログラムの流れと子どもの行為および場の対応関係か ら空間構成のあり方を論じたもの、青木・竹下ら ${ }^{8) 911011)}$ による、保 育者による子どもへの介助行為の合理化・円滑化に着目した設計手 法を論じたものがあり、3 歳未満児の保育室の設計要件が明らかに されている。しかし、これらにおいて 1 歳児クラスの人数規模とい う視点からの分析は行われていない。また、これらの研究成果が報 じられた後に、保育所保育指針の内容について大きな転換点があっ

\footnotetext{
*1 日本女子大学大学院人間生活学研究科生活環境学専攻 大学院生・修士 (工学) / 侏ミミサワホーム総合研究所 主任研究員
}

*2 日本女子大学住居学科 教授 $\cdot$ 博士 (工学)
Grad. Student, Graduate School of Human Life Science, Division of Living environment, Japan Women's University, M.Eng. / Senior Researcher, Misawa Homes Institute of Research and Development Co., Ltd.

Prof., Dept. of Housing and Architecture, Japan Women's University, Dr.Eng. 
たことを指摘したい。保育者が中心となり子どもを指導する保育 ${ }^{12)}$ から、1990 年改訂の保育所保育指針 ${ }^{13)}$ では、「子どもが自発的・意 欲的にかかわれるような環境の構成」を通して、「子どもの主体的な 活動を大切にし」、それを「保母が援助する」保育へ転換している。 なお、この基本方針は現在の保育所保育指針 ${ }^{1)}$ においても引き継が れている。そのため、“子どもの主体的な活動を大切にした環境” 1 という視点から、改めて保育所の空間構成のあり方を検討すること が求められる。以上のように、保育プログラムの流れ、行為と空間 の使われ方について、1 歳児のクラス人数規模と保育方法、空間構 成の関係を総合的にみた研究は少なく、“子どもの主体的な活動を大 切にした環境” 1) という視点から、クラス人数規模と空間構成のあ り方について考察を行う点に、本研究の特徵がある。

\section{2. 研究方法}

\section{2-1 調査対象}

同一運営主体による私立認可保育所の中から、1 歳児クラスの人 数規模が $10 \sim 14$ 人前後、 20 人以上の 2 つのカテゴリからそれぞれ 2

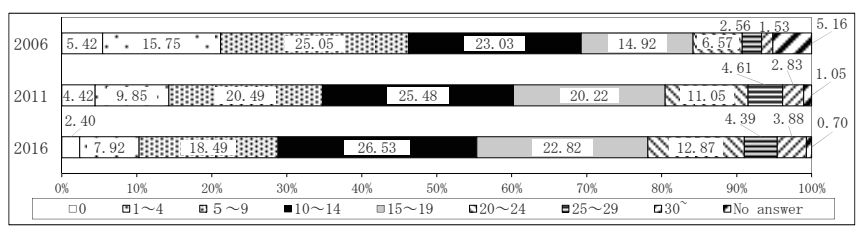

Fig. 1 Changes in Group Size of $1-$ Year-0ld-Class ${ }^{2) 3)}$ 4) 注4)

Table1 Outline of the Survey

\begin{tabular}{|c|c|c|c|c|c|c|c|c|}
\hline TYPE & No. & Date & Time & Enrollment & $\begin{array}{l}\text { Number of } \\
\text { Attendees }\end{array}$ & \begin{tabular}{|c|} 
Number of \\
Class Teachers
\end{tabular} & Weather & Temperature \\
\hline \multirow{6}{*}{ A } & a1 & 2017.10 .24 & \multirow{6}{*}{$\begin{array}{l}9: 00- \\
17: 00\end{array}$} & 16 & 14 & \multirow[t]{6}{*}{ 年 } & Sunny cloudy & $18^{\circ} \mathrm{C}$ \\
\hline & a2 & 2017.11 .28 & & 16 & \multirow{2}{*}{$\frac{13}{12}$} & & Cloudy & $15^{\circ} \mathrm{C}$ \\
\hline & a3 & 2017.12 .19 & & 16 & & & Sunny & $12^{\circ} \mathrm{C}$ \\
\hline & a4 & 2018.01 .26 & & 16 & 16 & & Sunny & $5^{\circ} \mathrm{C}$ \\
\hline & a5 & 2018.02 .22 & & 16 & 15 & & Sometimes snow cloudy & $6^{\circ} \mathrm{C}$ \\
\hline & 26 & 2018.03 .20 & & 16 & 12 & & Sometimes rain cloudy & $11^{\circ} \mathrm{C}$ \\
\hline \multirow{5}{*}{ B } & b1 & 2017.10 .17 & \multirow{5}{*}{$\begin{array}{l}9: 00- \\
17: 00\end{array}$} & $\frac{11}{11}$ & $\frac{12}{10}$ & \multirow{5}{*}{3} & Rainy & $13^{\circ} \mathrm{C}$ \\
\hline & $\mathrm{b} 2$ & 2017.11 .22 & & 11 & 11 & & Sunny cloudy & $8^{\circ} \mathrm{C}$ \\
\hline & b3 & 2017.12 .18 & & 11 & 11 & & Sunny & $4^{\circ} \mathrm{C}$ \\
\hline & $\mathrm{b} 4$ & 2018.01 .15 & & 10 & 10 & & Sunny cloudy & $4^{\circ} \mathrm{C}$ \\
\hline & b5 & 2018.02 .26 & & 10 & 10 & & partly cloudy & $7^{\circ} \mathrm{C}$ \\
\hline \multirow{6}{*}{ c } & $\mathrm{c} 1$ & 2017.10 .06 & \multirow{6}{*}{$\begin{array}{l}9: 00- \\
17: 00\end{array}$} & 27 & 23 & \multirow{6}{*}{6} & Cloudy & $17^{\circ} \mathrm{C}$ \\
\hline & $\mathrm{c}^{2}$ & 2017.11 .10 & & 27 & 23 & & Sunny & $13^{\circ} \mathrm{C}$ \\
\hline & $c 3$ & 2017.12 .07 & & 27 & 24 & & Sunny & $8^{\circ} \mathrm{C}$ \\
\hline & $c 4$ & 2018.01 .29 & & 27 & 22 & & Sunny & $10^{\circ} \mathrm{C}$ \\
\hline & $c 5$ & 2018.02 .15 & & 27 & 21 & & Sunny & $15^{\circ} \mathrm{C}$ \\
\hline & $c 6$ & 2018.03 .26 & & 27 & 19 & & Sunny & $17^{\circ} \mathrm{C}$ \\
\hline \multirow{5}{*}{ D } & $\mathrm{d} 1$ & 2017.11 .24 & \multirow{5}{*}{$\begin{array}{l}9: 00- \\
17: 00\end{array}$} & 24 & 21 & \multirow{5}{*}{4} & Cloudy & $14^{\circ} \mathrm{C}$ \\
\hline & d2 & 2017.12 .21 & & 24 & 21 & & Sunny & $8^{\circ} \mathrm{C}$ \\
\hline & d3 & 2018.01 .18 & & 24 & 20 & & Sunny & $12^{\circ} \mathrm{C}$ \\
\hline & d4 & 2018.02 .27 & & 24 & 24 & & Sunny & $9^{\circ} \mathrm{C}$ \\
\hline & d5 & 2018.03 .14 & & 24 & 23 & & Sunny & $20^{\circ} \mathrm{C}$ \\
\hline
\end{tabular}

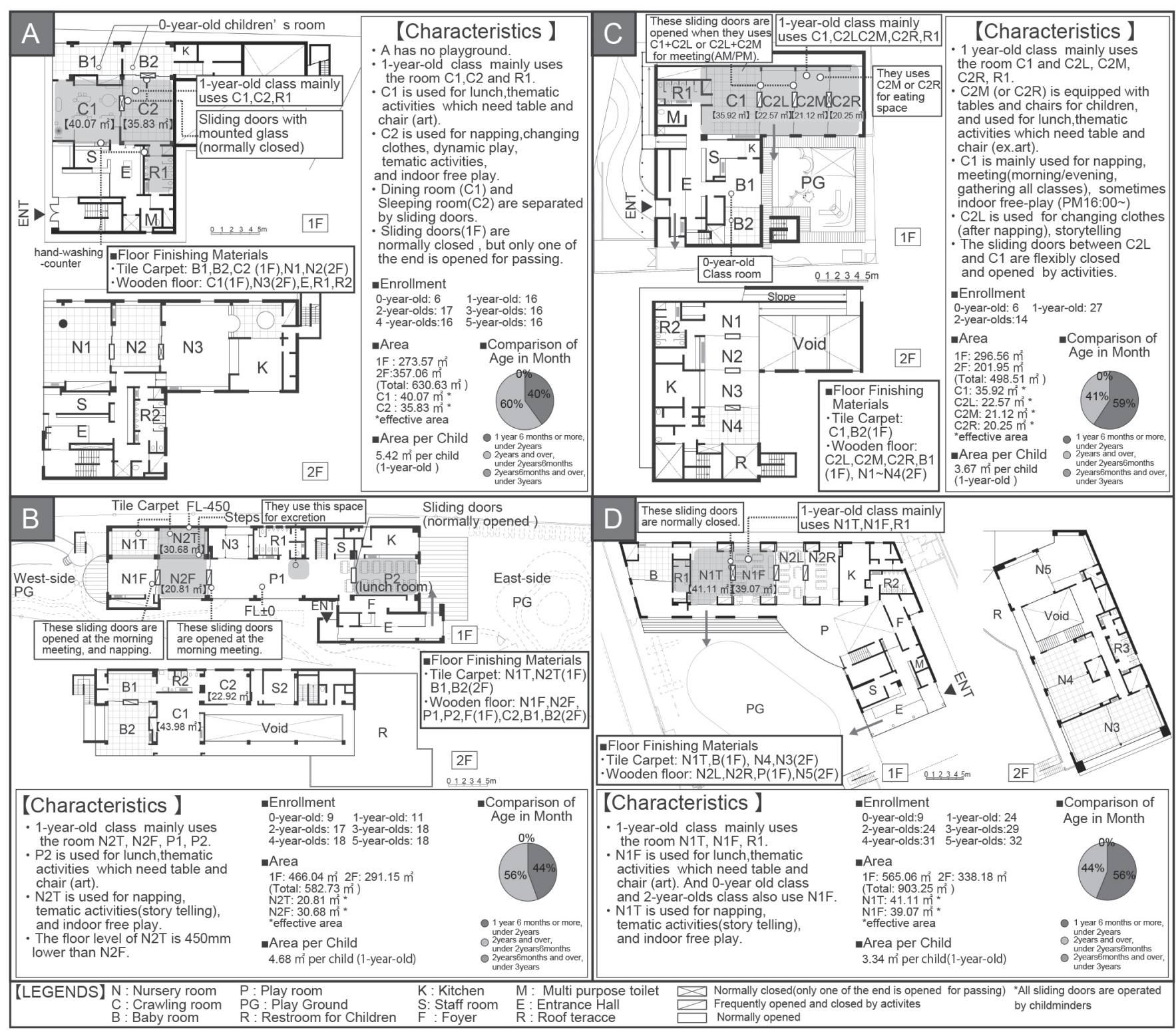


園、計 4 園を選択した。クラス人数規模の設定について、Fig. 1 よ り 1 歳児の人数規模の現状は「10人〜 14 人」が最も多く、また近年 20 人以上の規模が増えていることから、上記の 2 つのクラス人数規

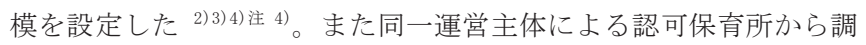
查対象を選出した理由は、保育理念が同一であり、保育理念および 保育方針の違いからの影響が少なく、より子ども及び保育者の行動 と建築環境要素との関係を比較検討しやすいと推察されるためであ る。調查対象園概要および各園の平面図をFig. 2 に示す。

\section{2-2 研究方法と分析手順}

調查期間は 2017 年 10 月から 2018 年 3 月迄である (Table. 1)。午 前 9 時から午後 5 時の間、2017 年 4 月 1 日時点で満 1 歳児にある幼 児で編成された、1 歳児クラスを対象に参与観察調查を実施した。 各活動場面における子どもと保育者の様子を 10 分間に 1 枚のメモを 取り、あわせて写真撮影にて記録し分析を行った。また普段の子ど もの様子を観察する目的から、原則としてお誕生日会等の特別行事 のない日を選択した。ここで得たデータを元に、“子どもの主体的な 活動を大切にした環境” 1) の視点から、各園で違いが最も現れてい た場面のうち、典型的な事例を選び、空間の使われ方、保育者及び 子どもの動きについて分析を行った。

なお調査、研究にあたって、以下の 3 つの手順で分析を行った。 まず (1) 保育プログラムの流れと行為の重なり方を観察し、各園で違 いが見られた場面を把握する。続いて (2)行為が重なりやすく混乱が 生じやすい活動の移行場面について、保育者および子どもの動きと 空間の使われ方をみていく。最後に、(3) “子どもの主体的な活動 を大切にした環境” 1)の視点からの分析である。“子どもの主体的な 活動を大切にした環境” 1) とは、保育所保育指針 ${ }^{11}$ および保育環境 の質に関する評価指標のひとつ「保育環境評価スケール (2)<乳児版

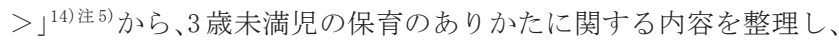

・ある活動を継続中の児と、次の活動に移行した児とが互いにそれ ぞれの行為を阻害されず、落ち着いた環境の中で行えているか ・子どもが待たされる場面が少ない

・身の回りの事を自分でしょうとする子どもの気持ちを受け入れや すい(自分で靴を履く、食事することが保障された空間であるか)

とした。以上 3 つの視点から、保育の流れ、各活動場面における空 間の使われ方と子ども及び保育者の様子を見ていき、クラス人数規 模との関係を分析する。

\section{$2-3$ 言葉の定義}

集団規模に関する言葉の定義を行う。本報において「現員」とは、 実際に入所している子どもの人数をさす。「出席人数」とは、調査当 日に登園した子どもの人数とする。「グループ人数規模」とは保育所 での各活動場面において形成される、子どもの集まりの人数規模と する。また調查対象の保育所は 4 月 1 日において同じ年齢にある乳 幼児で編制された年齢クラス毎に保育を行っている。したがって、 各年齢クラスの現員規模を「クラス人数規模」と表記する。

\section{3. 月齢構成}

2017 年 10 月時点における、各園 1 歳児クラスの月齢構成比を Fig. 2 に示寸。対象児のうち、最少月齢児は 1 歳 6 ケ月（A, C, D )、
最高月齢児は 2 歳 5 ケ月である。なお対象園では基本は 1 歳児クラ スという集団単位で保育を行っているが、C のみ、活動場面によっ ては月齢毎に編成された 3 つのグループ単位で保育を行っている 注 6)。具体的には、(1)組 (2 歳 5 ケ月から 2 歳 1 ケ月までの高月齢児, 10 名)、(2)組（2 歳から 1 歳 9 ケ月までの児、9 名)、(3)組（1 歳 6 ヶ月から 1 歳 8 ケ月までの低齢児、8 名）である。

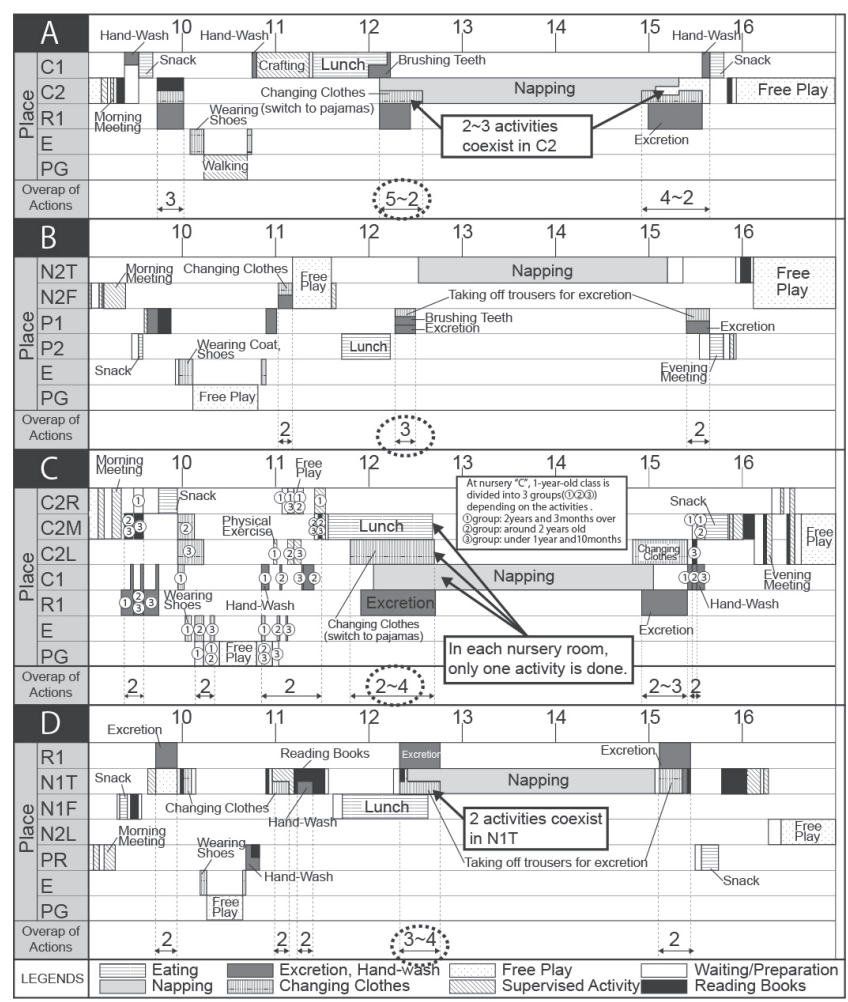

Fig. 3 Daily Schedule and Place (2017.11)

\section{4 . 保育プログラムの流れと行為の重なり \\ 4-1 保育プログラムの流れ}

各園の生活プログラムの流れをFig. 3 に示す。朝会一おやつ一戸 外活動一昼食一午睡一おやつ一室内自由遊び、という保育プログラ ムの流れは全園共通していた。違いが見られた点は、読み聞かせ・ 手遊びの場面の入り方と、昼食開始から全員が食べ終わるまでの時 間及び昼食開始から全員が排泄を終え午睡に入る準備が終わるまで の時間長さである。読み聞かせ・手遊びの場面は、A 及び B では午 前と午後にそれぞれ $1 \sim 2$ 回程度実施されているが、C 及び D では、 読み聞かせ・手遊びの場面が増加し、戸外活動後や食事前の手洗い、 または排泄と並行して行われる場面が目立つ。昼食開始から全員が 食べ終わるまでの時間について、C・D 園が、A・B 園に比べ長くなる 傾向がみられた注7)。なお昼食後に A 園では歯磨き及び寝間着への着 替えが行われ、 B 園は歯磨きが、C 園では寝間着への着替えが行われ ているが、D 園では寝間着への着替え、歯磨き共に行われていない (Fig3)。食事開始から全員が排泄を終え午睡に入る準備ができるま での時間長さについて、D 園は A 園とほぼ同じ時間長さであった (Fig3)。このため、D 園において寝間着への着替え及び歯磨きが実 施されるならば、更にこの時間は長くなると推察される。

\section{4-2 行為の重なり}

4 園ともに、昼食から午睡の移行場面での行為の重なりが多い 


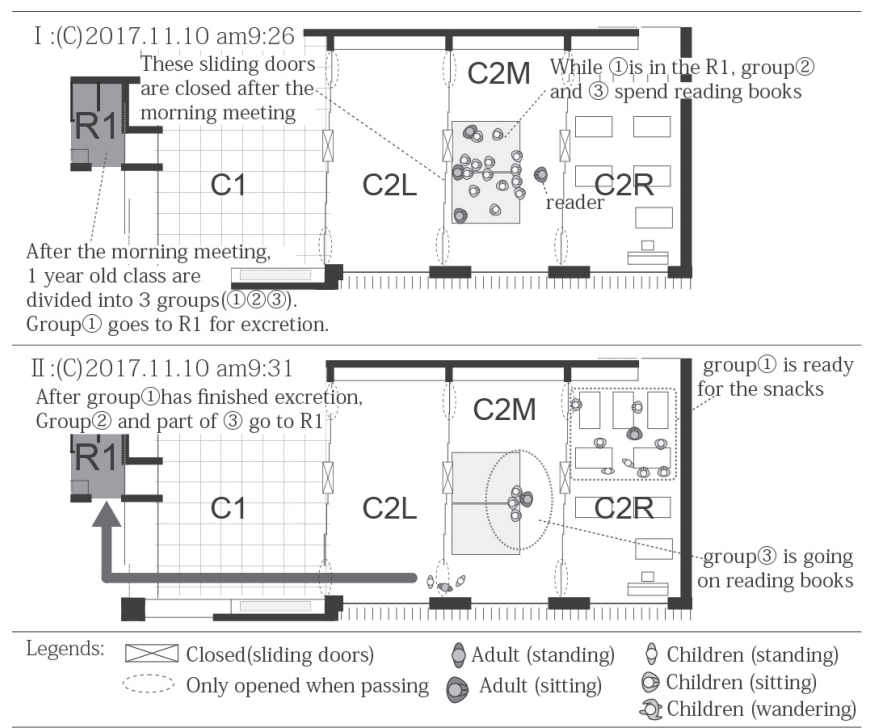

Fig. 4 Scenes of Transition from Meeting (AM) to Excretion (C)

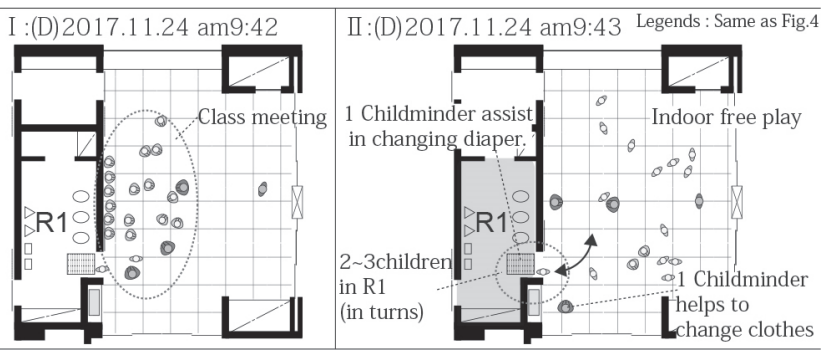

Fig. 5 Scenes of Excretion and Indoor Free Play (D)

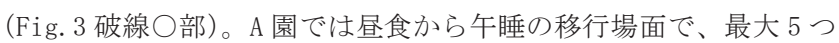
の行為が、B・C・D 園では、3〜4の行為が同時に重なる時間帯が観 察された。更に A D D 園は同一室内において、午睡と着替え、読み聞 かせと排泄の順番待ちなどの複数行為が並行して行われている様子 が観察され、午睡時に使用する部屋を中心に、多種多様な活動が行 われていることが読み取れる。また C・B 園では、同じ時間帯に複数 の行為が並行して行われるが、使用する部屋が分散しており、同一 室内で複数行為が並行して行われる場面が、A・D 園に比べて少ない 様子が見られた(Fig. 3)。

\section{5. 活動の移行場面の様子と空間の使われ方}

\section{$5-1$ 朝会から午前おやつへの移行}

$\mathrm{A} ・ \mathrm{~B} ・ \mathrm{D}$ 園では、1 歳児クラス単位でほぼ一斉に午前おやつ一移行 している。A 園では、C2 で 0 ・1 歳児クラスのみでの朝会を終えると、 読み聞かせを経て、2 3 名ずつ $\mathrm{C} 1$ 一移動し、手洗いをすませた児 から着席していく。B 園では、朝会を終えた後、曜日によっては英 語保育（毎週 1 日、全年齢クラス合同）を経て、年齢クラス毎に歩 いて P 2 へ移動し、午前おやつに入る。D 園は朝会が終わると、年齢 クラス毎に移動して午前おやつに入る。

一方 C 園では午前おやつの前に排泄の時間が設けられている。C 園での朝会から午前おやつへの移行場面における子どもと保育者の 動きをFig. 4 に示す。C 園では、全年齢クラス合同での朝会を終え ると、月齢別に編成された (1)・(2)・ (3)組に分かれ小グループ（1 グ ループ人数規模：8〜10 名）活動に移行し、まず高月齢児のグルー プ(1)組から R1 几移動し排泄に入る。この時、保育者は朝会時に 2

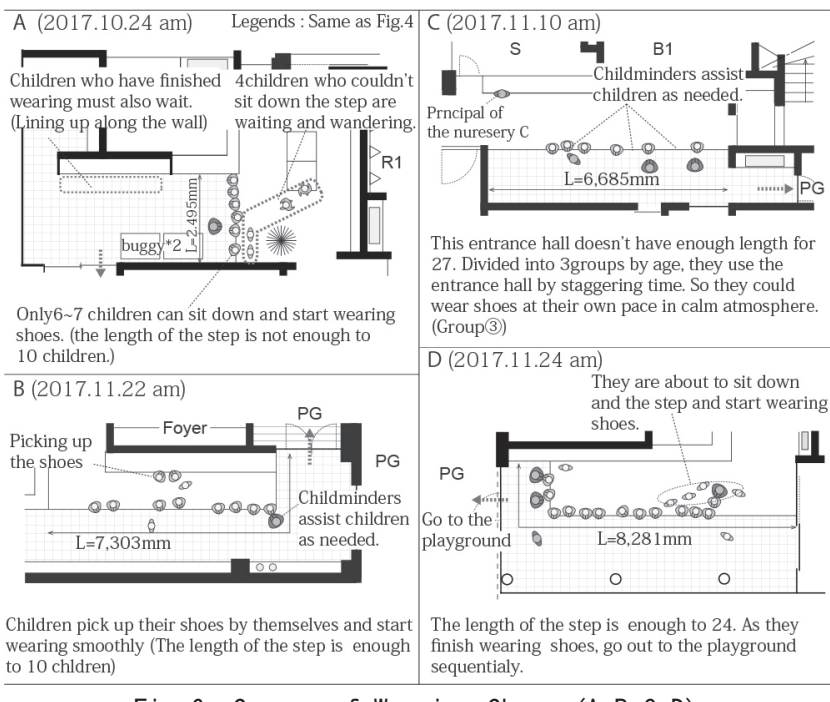

Fig. 6 Scenes of Wearing Shoes (A, B, C, D)

室一体利用していた C2L と C2M の間にあるスライディングウォール を閉め、2 室に区切る。(2)・(3)組は、この間 C2M で一緒に読み聞か せを受けていた（Fig. 4- I ）。(1)組が排泄を済ませ、C 1 で手洗いに 移ると、(2)・(3)組は 3 冊目を読み終えたところで、3 名（(3)組の一 部）を残し、(1)組と入れ替わりで排泄を済ませていく（Fig. 4-II）。 一方 $\mathrm{A} \cdot \mathrm{B} \cdot \mathrm{D}$ 園は午前おやつから戸外活動への移行場面において、 排泄の時間が割り当てられており、読み聞かせ・手遊びまたは室内 自由遊びと並行して排泄が行われている。例えばD 園では、午前お やつを終えると一斉に N1T に移動し、R1 側の壁沿いに、前後 2 列程 度に並んで座りクラス朝会を行なった後、そのまま室内自由遊びと 並行してR1 で排泄（おむつ交換）を行っていた(Fig. 5)。保育者は 室内自由遊びの場と、R1 内と R1 前（洋服の着脱の介助を行う）の 3 箇所に分かれて対応し、名前を呼ばれた子どもから順に $2 \sim 3$ 名ずつ $\mathrm{R} 1$ に入り、排泄を済ませていく。A 園では保育者 1 名が $\mathrm{C} 2$ で読み聞 かせをする中、もう一人の保育者が外遊び前の着替え（ジャンパー 及び帽子の着用）を介助していき、残り 1 名の保育者が R 1 で排泄 の介助を行っていた。A・D 園では、子どもは 2 3 名ずつ入れ替わ りで排泄を行うため、絵本の途中で排泄に入る場面も見られた。B 園では保育者 2 名で排泄の介助を行い、全員排泄を済ませた後で読 み聞かせが行われていた。

\section{$5-2$ 午前おやつから戸外活動への移行}

玄関の空間構成及び玄関で靴を履く場面の様子について Fig. 6 に 示す。園児は自分で靴を下駄箱から取り出し、順次上がり框部に腰 掛けて、保育者の介助を適宜受けながら靴等を履いていく。A 園で は上がり框部に子どもが 1 度に座れる人数は $6 \sim 7$ 人程度で、現員 16 名全員が座るのに充分な間口がない。座れなかった子どもは、先 に履き始めた子が履き終わるまで順番を待つ間、ホール内を探索し 始め、ソファの上を歩いて遊び、保育者に注意される場面が見られ た注 8)（Fig. 6-A）。また先に履き終えた子も、全員が履き終えるまで 待つ必要があり、靴等を履き始めてから出発までに要する時間が他 の 3 園より長くなる傾向が見られた。B 及び D 園では、1 歳児クラ スの子ども全員が座るのに十分な間口があり、各子どもが自立度に 応じて、保育者の介助を適宜受けながら、自分のペースで靴を履く 様子が観察された（Fig. 6-B, D)。C 園では、現員 27 名全員が座るの 


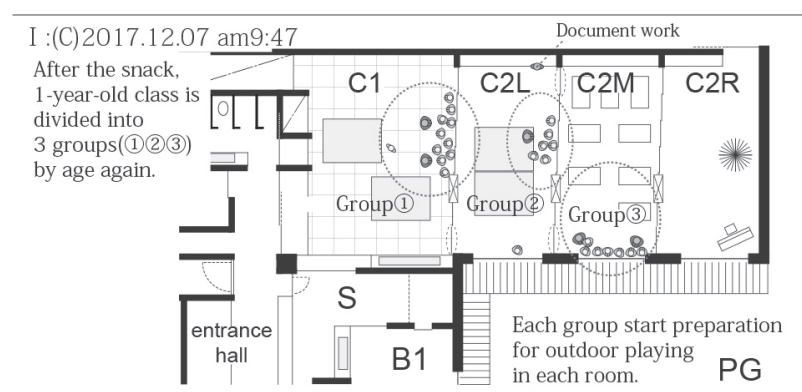

II :(C)2017.12.07 am9:51
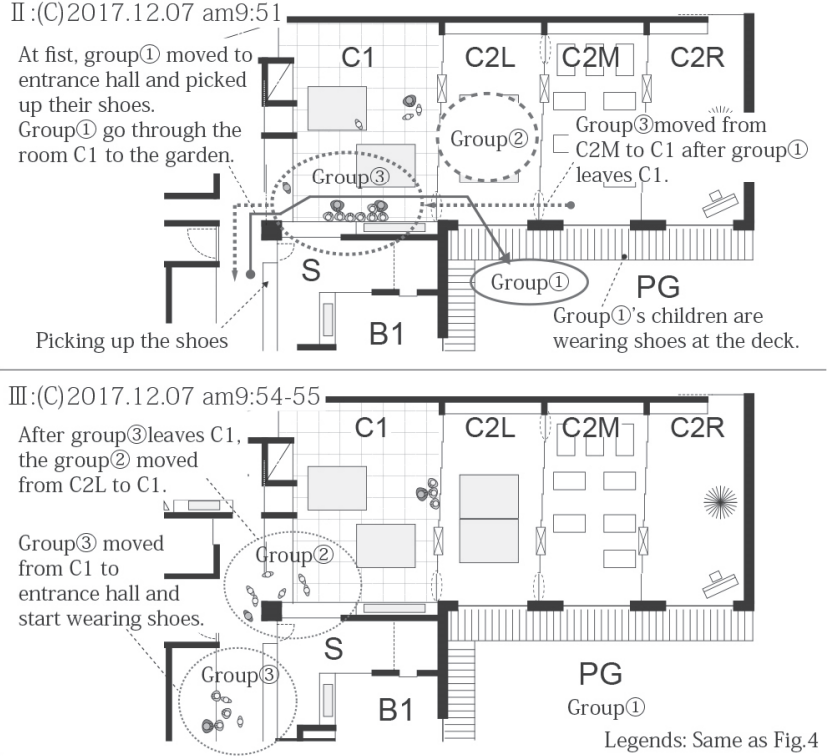

Fig. 7 Scenes of Transition from Snack to Outdoor Activity (C)

に十分な上がり框部の長さを有さないが、月齢毎に編成された(1)・ (2)・(3)組（グループ人数規模：8１0 名）に分かれ、それぞれ $\mathrm{C} 1$ 、 C2L、C2M の 3 つの場所に分かれて身支度を行い(Fig. 7- I )、身支度 に時間がかからない(1)組から順に、時間差をつけて玄関を利用する、 あるいは園庭のウッドデッキ部と 2 箇所に分散して利用し(Fig. 7II )、混乱もなくスムーズに園庭での戸外活動へと移行していた (Fig. 6-C, Fig. 7-III)。なお靴を履き始めてから全員が履き終える までの所要時間の平均は B・C 園（C 園は各グループの所要時間）で 約 5 分、D 園で約 3 分であった。A 園は靴下を履く時間が含まれてい るため、単純比較はできないが、約 8 分であった注 9 )。靴を履くスペ ース（上がり框部）が不足していた A 園において待つ場面がやや長 くなる結果となった。

\section{$5-3$ 昼食から午睡への移行}

$\mathrm{A} ・ \mathrm{~B} ・ \mathrm{D}$ 園は食事開始後 30 分頃を目安に、食事を終えていない児 を残し、一斉に移動して着替え及び排泄に移行する。一方 C 園では 食事開始後 15 分頃から、完食した児から順次歩いて移動し、着替え に入るという違いが見られた。

A 園では C 1 で食事をとり、30 分経過した頃から完食した児から 歯磨きに入る。歯磨きを $5 \sim 6$ 分で終えると、食事を終えていない览 (5 名)を残し、ほぼ一斉に C 2 一移動する (Fig. 8-II )。その後着替え コーナーで着替えをし、R 1 で排泄を済ませた児から午睡に入ってい く(Fig. 8-III)。このため C 2 には、午睡中の子どもと、着替えまた は排泄の順番を待つ児が混在し、順番を待つ間、布団のまわりを走 り回る児や、布団に入った後も先生の寝かしつけが待てずに起き上 がる児など、なかなか午睡に入らない児の姿が観察された注 10)。

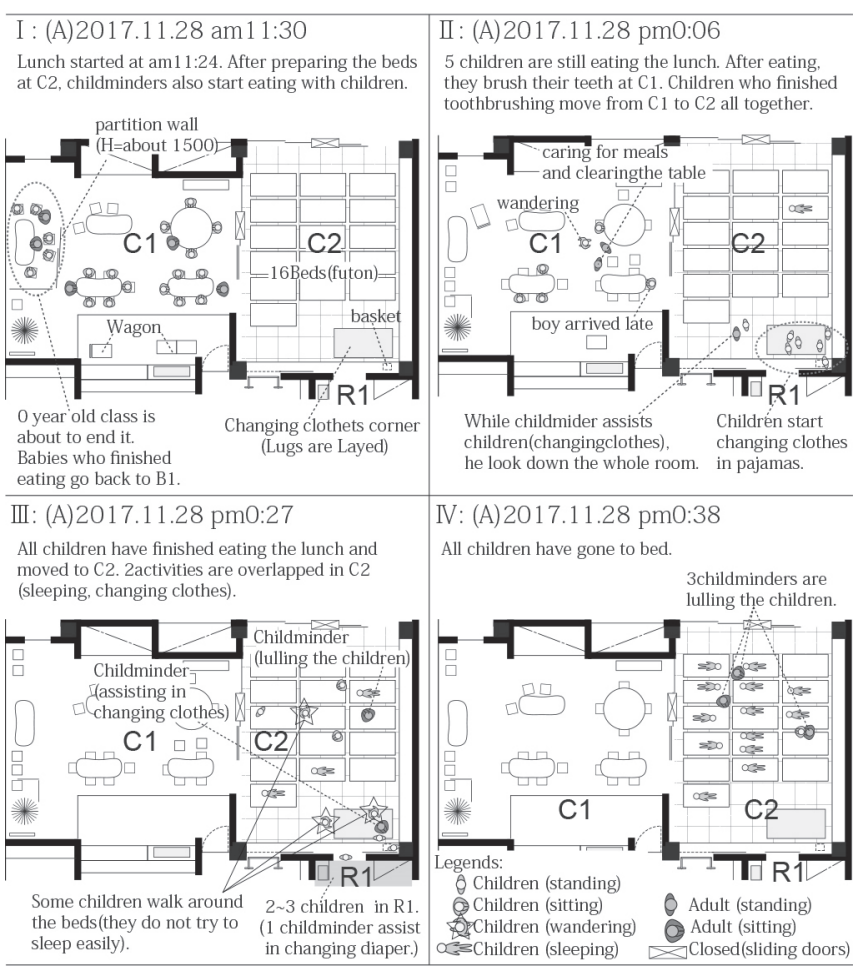

Fig. 8 Scenes of Transition from Lunch to Napping (A)

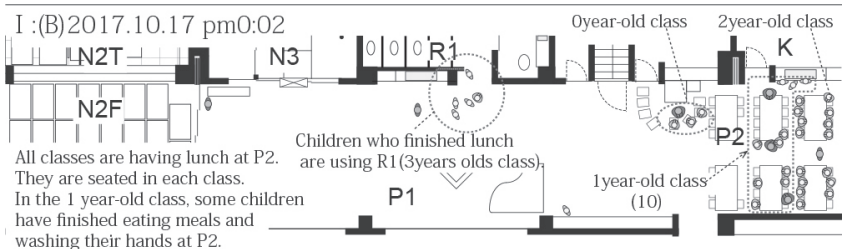
\begin{tabular}{llll}
\hline$\Pi$ :(B) 2017.10.17 pmO:08 & $\begin{array}{l}\text { After finishing tooth brushing } \\
\text { and diaper change at P 1, } \\
\text { l year-old class moves to N2T }\end{array}$ & $\begin{array}{l}\text { They give medicine } \\
\text { to the children }\end{array}$ & $\begin{array}{l}\text { 2children } \\
\text { still keep }\end{array}$
\end{tabular}

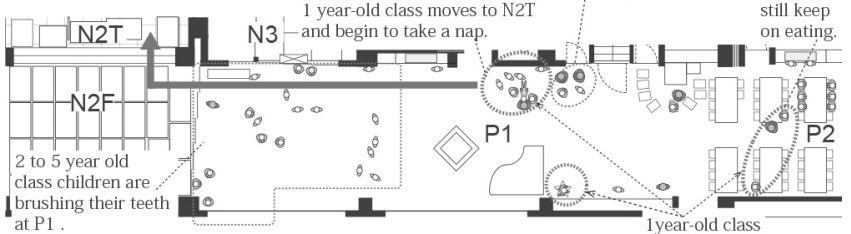
at $\mathrm{P} 1$

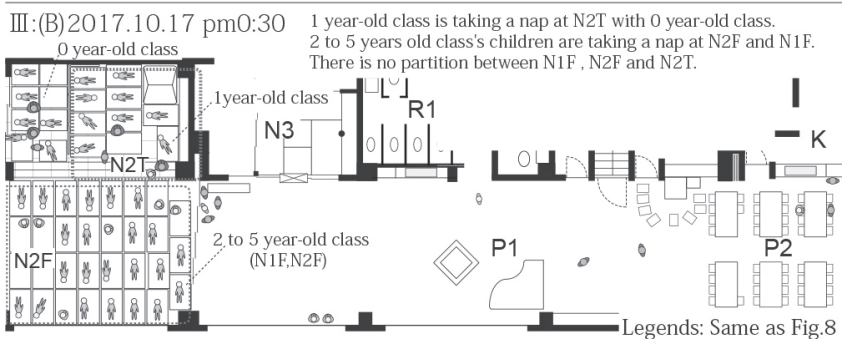

Fig. 9 Scenes of Transition from Lunch to Napping (B)

B 園での昼食は、1 歳児から 5 歳児クラスの児で編成された縦割り班 （1テーブル 8 名〜10名）で行う場合と、年齢クラス別のテーブル に分かれて行う場合がみられた(Fig. 9- I )。全クラスで揃って食事 終了時の挨拶を終えると、1 歳児クラスの児は保育者と一緒に P 1 (R1 入口付近) にクラス単位で移動する (Fig. 9- II)。そこで保育者 2 〜3 名が歯磨き・着替え・排泄の介助に入り、全て済ませた後に一 斉に移動するか、用の済んだ児から順次歩いて N2T 一移動し、午睡 に入る (Fig. 9-III)。挨拶をしてから午睡に入るまでの所要時間は 10 分程度で最も短く、午睡の場（N2T）で騒ぐ様子も見られなかった。 


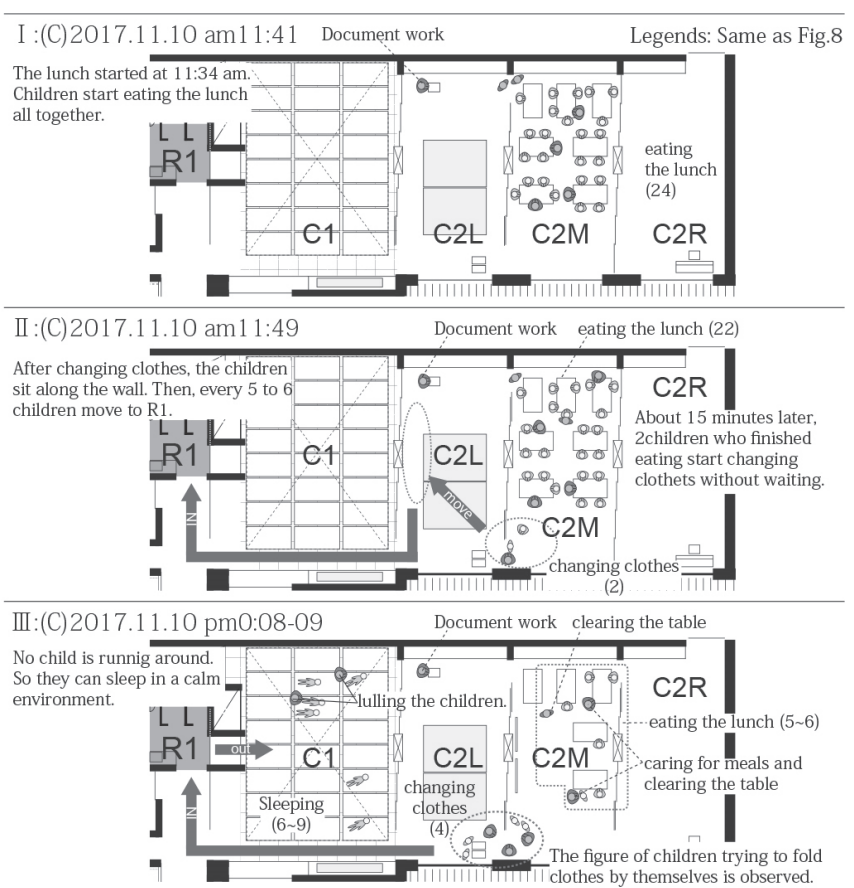

Fig. 10 Scenes of Transition from Lunch to Napping (C)

C 園では昼食開始後 15 分頃から、完食した児から順次歩いて C2L に移動し、着替えをはじめていた(Fig. 10-II)。他の場面では、月齢 毎に編成された小グループ単位で行動していたが、ここでは、他の 児を待つことはせず、食事を終えた子どもから着替えに移行してい る。保育者は子どもが完食したのを見計らい、C2M と C 2 L の境界付 近に座り、着替えの介助に入っていた。着替え終えた児は C $2 \mathrm{~L}$ の壁 沿いに座って待ち、着替えを終えた児が 3〜 名程度になったところ で、保育者 1 名と共にトイレへ移動する。排泄を済ませた児から順 に午睡へ入っていく(Fig. 10-III)。布団に入ってから多少の話し声は 聞こえるが、起き上がって布団のまわりを走り回る姿や、騷ぐ様子 は見られず、落ち着いた環境の中で午睡に入ることができている。C 園は他の 3 園に比べ、2 以上の生活行為が並行して行われる時間が 長く、昼食開始から全員午睡に入るまでの所要時間も長いが、スラ イディングウォールで分割された空間 C $2 \mathrm{M} 、 \mathrm{C} 2 \mathrm{~L}$ を、食事 (C2M) 着替え $(\mathrm{C} 2 \mathrm{~L})$ - 排泄 $(\mathrm{R} 1)$ - 午睡 $(\mathrm{C} 1)$ の活動の流れに沿って場を変え 移動し (Fig. 10)、場所と行為を 1 対 1 で対応させて、それぞれの活 動が阻害されずに行われている様子が見られた。

D 園でも食事開始後 15 分ごろから昼食を完食した児が表れ始める が、食事開始後 30 分経過した頃に、食べ終えた 1 歳児クラスの約半 数の子ども（10 名）が、N 1 T に移動する (Fig. 11-II)。まず手洗い カウンター前に集まり、読み聞かせと並行して 2 名ずつ入替りで排 泄（R1 内）を済ませ、午睡に入る (Fig. 11-III, IV)。寝巻きへの着替 えはしないが、排泄に伴うズボンの脱ぎ履きはN 1 T で行っている。 この間、排泄・読み聞かせ・午睡が並行して行われる場面が見られ、 N 1 T 内では午睡に入る児がいる中で、排泄を待つ児や、排泄を終え た児が蚊帳や布団のまわりを走り回り、保育者がそれを注意する姿 が観察され、午睡の場としての静かさ、落ち着きが確保しら゙らい様 子が見られた(Fig. 11-V)。

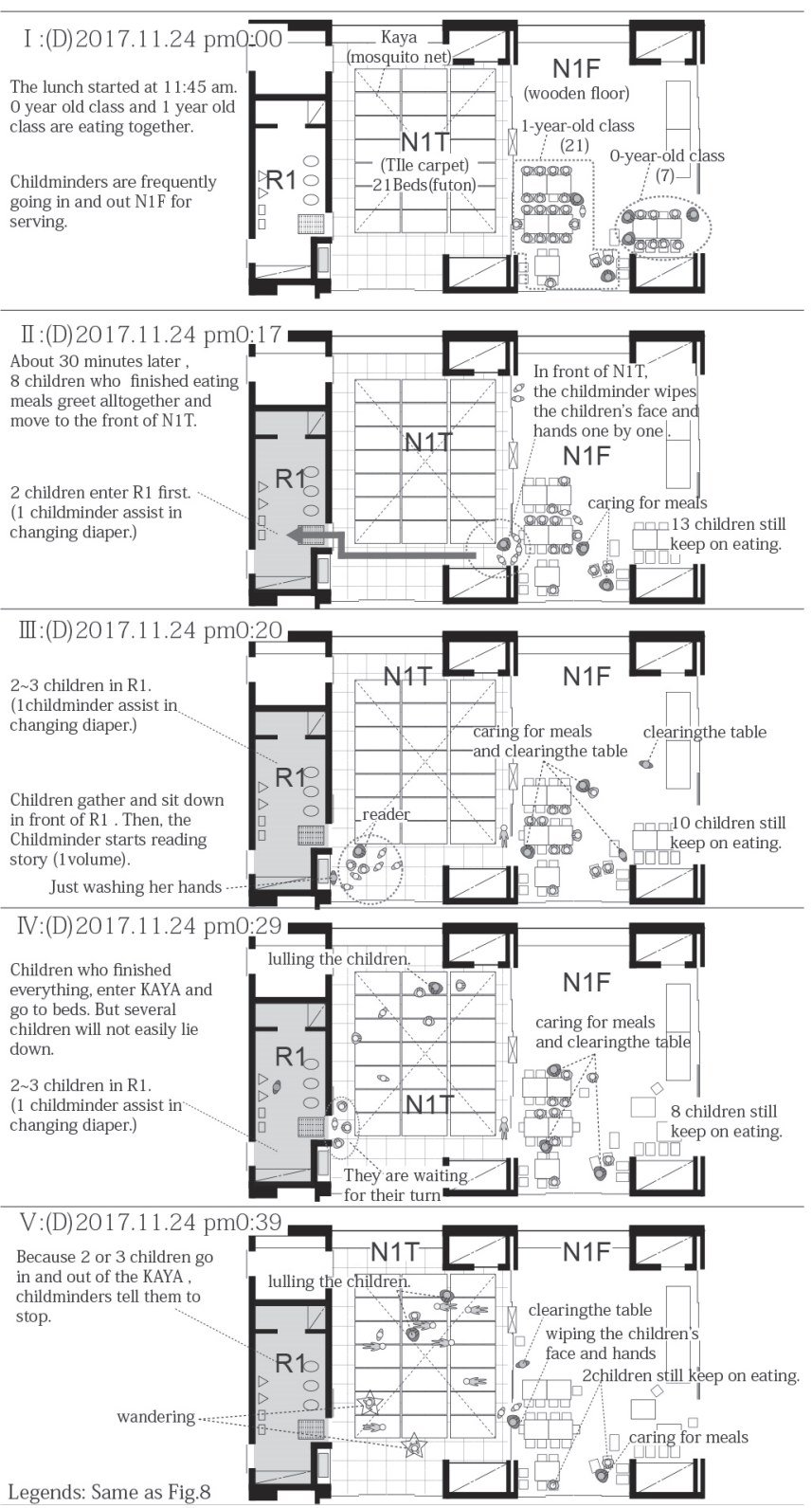

Fig. 11 Scenes of Transition from Lunch to Napping (D)

\section{6. 保育の流れからみた空間構成}

調查結果から、食事から午睡の移行場面において、行為の重なりが 最も多くなる傾向が見られた。またクラス人数規模が 20 人以上 (C. D 園)の場合、手洗い・排泄の場面等において子どもが待つ場面が増 え、食事から午睡の移行場面が長くなる傾向が見られた。このこと からクラス人数規模が大きい場合、昼食から午睡への移行場面に着 目し空間構成を検討寸ることが重要であるとわかった。ここで食事 から午睡への活動の移行場面における、空間の使われ方および保育 者と子どもの動きから、食事の場-着替えの場-トイレ（排泄）-午睡 の場の位置関係について、ハブ型 $(\mathrm{A} ・ \mathrm{D}$ 園)、スライド型 $(\mathrm{B} ・ \mathrm{C}$ 園 $)$ の 2 つに分類した (Fig. 12)。各タイプの特徴は以下の通りである。

I 、ハブ型 $(A \cdot D$ 園)

ハブ型とは、午睡に使用する部屋を中心点に、隣接する位置にあ る食事室とトイレを行き来する型である。動線が短く後述のスライ ド型に比心゙、保育者が 1 箇所で同時に複数行為（着替えと寝かしつ 


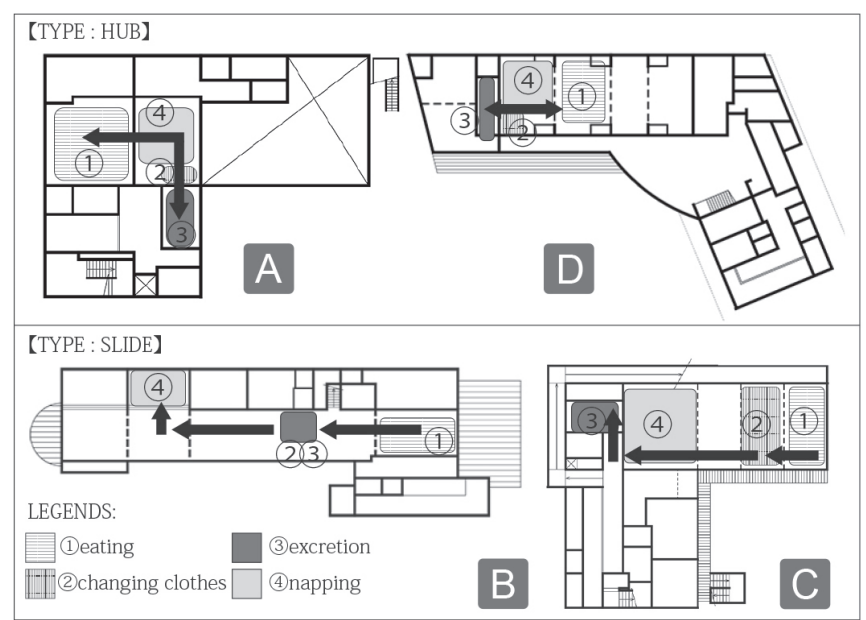

Fig. 122 Types of Layout

け、排泄の順番待ちの児）への対応がしやすい。しかし午睡に使用 する部屋で、着替え/午睡/排泄（順番待ち含む）/読み聞かせが並行 して行われ、複数行為が同時に 1 室に混在するため、午睡環境とし ての落ち着きが確保しづらい特徵がある。

II 。スライド型 $(\mathrm{B} ・ \mathrm{C}$ 園)

スライド型とは、昼食から午睡の流れに沿って、食事一着替え一 排泄一午睡の行為毎に利用空間をスライド移動する型である。1 ス ペース・1 行為の対応関係であるため、落ち着いた環境の中で着替 えや午睡に入る事が可能であり、待つ場面も比較的少ない。しかし、 各場所の保育者が対応寸る介助行為は基本 1 行為となるため、ハブ 型に比べ保育者の人数が多く必要となる可能性がある。また移動動 線が長くなりやすい特徵がある。

食事場面において、A・D 園（ハブ型）及び B 園（スライド型）で は、食事開始から約 30 分頃を目安に、食べ終えていない児ら数名を 残し、クラス単位で次の行為に一斉に移行寸る姿が観察されている。 一方 C 園（スライド型）では、食べ終わった児から順次着替えへと 移行させており、待つ場面が少なく、各子じものペースで、次の行 為へ移行する姿が観察されている。

午睡場面において、A・D 園（ハブ型）では、午睡中の児と、着替 えまたは排泄の順番を待つ児が 1 室内に混在し、布団のまわりを走 り回り、なかなか午睡に入らない监の姿が観察されている注 11)。一 方 B・C 園 (スライド型) では、着替えや排泄は午睡の場とは別の場 所で行われ、午睡室内での行為の重なりがなく、午睡中の览は阻害 されることなく、落ち着いた環境の中で午睡する様子が観察されて いる。以上のことから、食事から午睡への移行場面に着目した空間 構成において、午睡空間の落ち着きを確保する為には、スライド型 が望ましい。1 歳児クラスの職員配置基準（保育士数）注 12) におい て、クラス人数規模 19 人以上の場合、最低 4 名の保育士（国基準） が確保されるため、食事・着替え・排泄・午睡と各行為・場所ごと に一人ずつ保育士を配置することは可能であり、各子どものペース に対応しやすく、待つ場面が少ないことから、スライド型がより望 ましい。一方クラス人数規模が 18 人以下の場合、各行為・場所ごと に保育士を配置することは難しい注 ${ }^{13)}$ が、B 園のように、クラス単 位で一斉に次の活動に移行することで、スライド型に対応できる。

\section{7. 空間構成が保育方法に与える影響}

前項で掲出した空間構成別に、クラス人数規模と空間の使われ方、 保育方法の工夫について見ていく。

ハブ型（A・D 園）において、クラス人数規模の大きいD 園では、 食事開始から全員が食事を完了寸るまでの時間が長く、食事開始か ら全員排泄を終え午睡に入る準備が終わるまでの時間について、歯 磨きや寝間着への着替えを行っていないが、A 園とほぼ同じ時間を 要していた。また次の活動に移る前の場面において、ほぼ毎回読み 聞かせ・手遊びが入り、そこで手洗いや排泄が並行して行われる場 面が増えていた。A・D 園では、ほぼ終日クラス単位で活動している。 排泄や手洗いをクラス単位で行うならば、保育者の手を増やすか、 設備数（手洗いであれば水栓の数）を増やさない限り、子どもの人 数が多いほど所要時間は長くなり、待つ場面が増えることが予測さ れる。このため、手洗い・排泄の時間が単なる待ち時間とならない ように、読み聞かせと並行して排泄や手洗いを行い、保育方法の工 夫で対処していると推察される。

スライド型 $(\mathrm{B} ・ \mathrm{C}$ 園) においても、クラス人数規模の大きい $\mathrm{C}$ 園 で行為の重なりが増え、昼食から午睡への移行時間が長くなる傾向 が観察されている。昼食から午睡への移行場面では、B 園はクラス 単位（10１1名）で移動し着替え等に入るが、C 園ではスライディ ングウォールで分割された C2M (食事)、C2L (着替え)、C1 (午睡)を、 1 空間 1 行為で対応させて使い、食べ終えた児から順次着替えに移 行し、子どもにより個人差の大きい食事場面で個別対応をする姿が 見られた(Fig. 10)。C 園ではクラス単位での活動の他、排泄や外遊 びへの移行場面において、月齢毎に編成された 3 つの小グループ（1 グループ人数規模：8～10 名）に分かれ、居場所も $\mathrm{C} 1 、 \mathrm{C} 2 \mathrm{~L} 、 \mathrm{C} 2 \mathrm{M}$ と 棲み分けて別行動をする場面が観察されている(Fig. 4, 7)。これはグ ループ間で玄関やトイレを利用する時間をずらし、子どもが待つ場 面を減らす工夫をしていると読み取れる。

更にC 園で観察された、子どもと保育者の関わり方についても触 れておく。子どもと保育者の関わり方には、特定の保育者が特定の 子どもを見る担当制と、子どもの担当を決めずに、チームで保育を 行う担任制（複数担任制）がある。調查対象園は複数担任制であり、 中心的な保育者 1 名が呼びかけを行い、残りの保育者と一緒にチー ム全員で園児を見ている。しかし C 園では、(1)朝会から午前おやつ 一の移行場面 (排泄の時間) および(2)外遊び一の移行場面において 見られた月齢毎の小グループ活動時は、各グループをいつも同じ保 育者が対応しており、担当制のような動き方をしている様子が観察 されている。担当制は一人の保育者で担当の子どもの保育を全て対 応する為、保育者の負担が大きい欠点があるが、子どもと保育者の 間に信頼関係を深めやすいといわれている。C 園は調査対象園の中 で最もクラス人数規模が大きく、待ち時間が長くなることや、子ど も一人一人の個への対応が難しくなることが予想された。しかし活 動場面によってグループ人数規模を小さくし、スライディングウォ ールで分割された空間に分散して活動し、子どもが比較的待つこと なく落ち着いた環境の中で過ごしていたことから、子どもの“個” を認めることと、集団生活との両立がしや寸い空間環境が確保され ていると認められる。 


\section{8.まとめ}

1 歳児クラスの人数規模について、現状において最も多いとされ る 10 人 14 人前後のクラス人数規模を有する 2 園と、近年増加し つつある 20 人以上のクラス人数規模を有する 2 園の計 4 園を対象に、 “子どもの主体的な活動を大切にした環境” 1) という視点から、保育 プログラムの流れ、空間の使われ方とそこでの子ども及び保育者の 動きと様子について分析を行い、クラス人数規模と保育室の空間構 成のあり方について考察を行った。その結果、保育プログラムの流 れにおいて、クラス人数規模が 20 人以上の園 $(C \cdot D$ 園) において、 準備・整列・移動時間の場面が増え、また昼食から午睡への活動の 移行場面の時間が長くなり行為の重なりも増える傾向が見られた。

続いて各活動の移行場面において、クラス人数規模によって子ど もと保育者の動き方及び空間の使われ方に違いが見られた (1) 朝会 から午前おやつへの移行、（2）午前おやつから戸外活動への移行、 （3）昼食から午睡への移行の 3 つの場面について、“子どもの主体的 な活動を大切にした環境” 1) という視点から分析を行った。ここか ら得た設計指針は以下の 3 点である。

1. 子どもが待つ場面を減らす空間の工夫

子どもが「待つ」場面には、特定の場所に利用が集中し順番待ちを する場面、食事など、子ども間で個人差が出やすい生活行為におい て、先に終えた児が他の児が終わるまで待つ場面が挙げられる。こ の子どもが「待つ」場面を減らす設計上の工夫として、前者につい ては、設備数（便器や手洗いカウンターの水栓の数）を増やすか、 玄関の場合、クラス人数規模に合わせて、靴を履くスペース（ここ では上がり框部の長さ）を用意することが望ましい。それが叶わな い場合は C 園のように、活動場面によって一時的に少人数グループ を編成し、時間をずらして玄関や手洗いカウンター等を利用する方 法がある。このとき各グループが利用可能な複数の空間が確保され ていることが望ましい。後者については、次点と重なるが、食事一 着替え一午睡の場とそれぞれ区切られた空間を用意することが望ま しい。これにより、食べ終えた児から順次移動して着替えに入るこ とができ、他の児が食べ終えるまで待たされることなく、次の活動 一移行しやすくなる。

\section{2. 子ども一人一人に対応しやすい空間の工夫}

クラス人数規模が 20 人以上の場合は特に、必要面積で保育室 1 室とするよりも、少なくとも 3 つ以上に区切られた空間とすること が望ましい。例えば行為の重なりが多い、食事から午睡への移行場 面において、食事一着替え一午睡をそれぞれ 1 空間 1 行為で対応さ せることで、食事が終わった児から順に場所を変え着替えに移るこ ともしやすく、各行為が互いに阻害されずに落ち着いて行うことが できる。すなわち子ども一人一人への対応がしやすくなる。また発 達状況にあわせた小グループを編成するなど、保育方法の選択肢を 増やすことにもつながる。

\section{3. 行為の流れと重なり方を視野に入れた平面計画}

行為の重なりが多い、食事から午睡への移行場面での空間の使わ れ方、保育者と子どもの動きから、食事一着替え一排泄一午睡の場 の位置関係について、ハブ型 $(\mathrm{A} ・ \mathrm{D}$ 園 $) 、$ スライド型 $(\mathrm{B} ・ \mathrm{C}$ 園 $)$ の
2 つに分類できた。食事から午睡への移行場面に着目した空間構成 において、午睡空間の落ち着きを確保する為には、スライド型が望 ましい。クラス人数規模が 19 人以上の場合、最低 4 名の保育士が 確保され、食事一着替え一排泄一午睡と保育士を 1 名ずつ対応させ ることができ、各子どものペースに対応しやすい観点から、スライ ド型がより望ましい。クラス人数規模が 18 人以下の場合、各行為・ 場所ごとに保育士を配置することは難しいが、クラス単位で一斉に 次の活動に移行することで、スライド型に対応できる。従って近年 増加しつつある 20 人以上のクラス人数規模の場合、複数行為の重な る場面が多いことから、面積広さに加え行為の流れにあった室の位 置関係、同一場所で同時に複数の行為が重ならないよう平面計画す ることが重要である。

以上のことから、1 歳児クラスの人数規模が 20 名以上の場合、昼 食から午睡の行為の流れに沿って、利用空間をスライド移動するス ライド型の空間構成が望ましいといえるが、その場合の平面計画に ついては保育室を必要面積で 1 室とするより、活動場面に応じて、 スライディングウォール等により複数に区切る事が可能な空間的な 仕掛けを用意することが望ましい。これにより (1)子どもの発達状況 に合わせて、一時的に小グループでの活動を展開するなどの選択肢 を保育者に与える、(2)家庭的な雰囲気や落ち着き感のある中で、一 対一の対応、子どものペースに応じた保育を行い易くなる、(3)バッ ファ的な空間を確保することで時間差をつけながら次の活動へ移行 しやすく、特定の空間に子どもが密集することを回避しやすくなる ことが確認された。

今回の調查対象 4 園は同一運営事業者による民間認可保育所であ り、同じ保育を目指している。与えられた空間で、目指す保育をど のように行うかは、保育者が保育のねらいを、空間の使い方として 落とし込む力による部分も大きい。このため今後の研究の展開とし て、保育者へのヒアリング・アンケート調査を通じて、保育者によ る空間の使いこなしの視点から検証を行う必要がある。また保育空 間を「区切る」手法には、スライディングウォールのほか、一般に はコーナー保育等をはじめとする家具什器による方法もある。スラ イディングウォール等の間仕切り建具による仕切り方とコーナー保 育による仕切り方とで保育における空間環境の質、保育方法がどの ように異なるのか、今後更に検証する必要がある。

\section{謝辞}

本研究にあたり、調査にご協力いただきました皆様に心から感謝 申し上げます。

\section{参考文献}

1) Ministry of Health, Labor, and Welfare: Hoikusyohoikushishin Heise i 29 nen Kokuji (Childcare Guidelines for Daycare Facilities, 29th year of the Heisei period edition), Flabel kan,2017.5(in Japanese) 厚生労働省 : 保育所保育指針<平成 29 年告示＞, フレーベル館, 2017.5 2) Social Welfare Corporation National Social Welfare Council Nationa 1 Child Care Council: Zenkoku Hoiku Kyougikai Kaiinn no Jittai Tyo usa Houkoku Syo 2016 (Survey report on the status of members of the National Council on Childcare 2016), http://www. zenhokyo. gr. jp/cyo usa/201706. pdf (in Japanese) (accessed 2018-06-18) 社会福祉法人全国社会福祉協議会全国保育協議会: 全国保育協議会会員の 実態調查報告書 2016, http://www. zenhokyo. gr. jp/cyousa/201706. pdf (参照 2018-06-18) 
3) Social Welfare Corporation National Social Welfare Council Nation al Child Care Council: Zenkoku no Hoikusyo Jittai Tyousa Houkoku S yo2011 (Nursery school survey report nationwide 2011), http://www. ze nhokyo. gr. jp/cyousa/201209. pdf (in Japanese) (accessed 2018-06-18). 社会福祉法人全国社会福祉協議会全国保育協議会: 全国の保育所実態調査 報告書 2011, http://www. zenhokyo. gr. jp/cyousa/201209. pdf（参照 2018 -06-18).

4) Social Welfare Corporation National Social Welfare Council Nation al Child Care Council: Zenkoku no Hoikusyo Jittai Tyousa Houkoku S yo (Nursery school survey report nationwide), http://www. zenhokyo.g r.jp/pdf/0805cyousa. pdf (in Japanese) (accessed 2018-06-18) 社会福祉法人全国社会福祉協議会全国保育協議会: 全国の保育所実態調査 報告書, http://www. zenhokyo. gr. jp/pdf/0805cyousa. pdf (参照 2018-0618)

5) Jyunichi S., Mari 0., Taeko S., Miki S., Nao M., Sanae H. : Hoiku n o Shitsu no Hyouka ni Kansuru Kenkyuu(Study on the Evaluation of $t$ he Quality of Day Care), Research on ChildcareScience, Vol. 1, pp. 1-2 1,2010 (in Japanese)

庄司順一, 尾木まり, 斎藤多江子, 須永美紀, 水枝谷尚, 椛沢早苗: 保育の 質の評価に関寸る研究, 保育科学研究, 第一巻, pp. 1-21, 2010

6) Nobuko 0., Junko I., Sachiko S. : SEPARATION OF SPACESE AT NURSERY R00M, A study on Nursery School Planning (1), Transactions of the Architectural Institute of Japan, No. 275, pp. 87-94, 1979.1(in Japan ese)

小川信子, 石井順子, 斎藤幸子:保育空間の機能分離 : 保育所の平面計画 に関する研究 (1), 日本建築学会論文報告集, 第 275 号, pp. 87-94, 1979. 1

7) Nobuko 0., Junko I., Sachiko S. : CHILDS' ACTIVITIES AND SPACE UTI LIZATION AT NURSERY SCHOOLS, A Study on Nursery School Planning (2), Transactions of the Architectural Institute of Japan, No. 276, pp. 123-131, 1979.2(in Japanese)

小川信子, 石井順子, 斎藤幸子: 保育所における生活と保育室の使われ方： 保育所の平面計画に関する研究 (2), 日本建築学会論文報告集, 第 276 号, pp. 123-131, 1979. 2

8) Masao A., Yasuharu K., Terukazu T. and Toshihiro K. : A STUDY ON TH E BABIES' ROOM PLANNING IN THE NURSERY SCHOOL, No. 1 The Use of the Nursery Room at Nursing Conversions Considering Babies' Group Acti vities, Transactions of the Architectural Institute of Japan, No29 3, pp. 127-137, 1980.7 (in Japanese)

青木正夫, 河野泰治, 竹下輝和, 北岡敏郎:保育所乳児部（3 歳未満児）の 平面用途構成に関する研究 その 1 保育の集団性と行為の転換時よりみた 保育室空間の使われ方の特徵, 日本建築学会論文報告集, 第 293 号, pp127137, 1980. 7

9) Masao A., Yasuharu K., Terukazu T. and Toshihiro K. : A STUDY ON T HE BABIES' ROOM PLANNING IN THE NURSERY SCHOOL, No. 2 "The Pre-arran ging Type", and the Necessity of Specialization of the Uses of a $\mathrm{N}$ ursery Space, Transactions of the Architectural Institute of Japan, No302, pp. 77-86, 1981. 4 (in Japanese)

青木正夫，河野泰治，竹下輝和，北岡敏郎：保育所乳児部（3 歳未満児） の平面用途構成に関する研究その 2 準備行為先行型と平面用途の分化要求, 日本建築学会論文報告集, 第 302 号, pp. 77-86, 1981.4

10) Masao A. and Terukazu T. : A STUDY ON THE BABIES' ROOM PLANNING IN THE NURSERY SCHOOL, No. 3 A research on the concept 'crawling room' and the conventional planning guide, Transactions of the Architect ural Institute of Japan, No. 314, pp. 143-153, 1982. 4 (in Japanes e)

青木正夫, 竹下輝和: 保育所乳児部（3 歳未満児）の平面用途構成に関する 研究その 3 ほふく室の空間概念と設計指針固定化の歴史的解析, 日本建築 学会論文報告集, 第 314 号, pp. 143-153, 1982. 4

11) Masao A. and Terukazu T. : A VERIFICATION ON THE USE OF THE BABIES' ROOM WITH" A SPARE SPACE”, A study on the babies' room planning in the nursery school No.4, Transactions of the Architectural Institu te of Japan, No.345, pp. 122-130, 1984.11 (in Japanese) 青木正夫，竹下輝和：「逃げの空間」をもつ平面用途分化型における使われ 方の検証 保育所乳児部 (3 歳未満児) の平面用途構成に関する研究 そ の 4 , 日本建築学会論文報告集, 第 345 号, pp. 122-130, 1984. 11

12) National Social Welfare Council「HOIKU NO TOMO」Editorial Depart ment: 「HoikusyoHoikushishin」Zenbun to Sono Mikata(「Childcare Gu idelines for Daycare Facilities」 Full text and commentary), Natio nal Social Welfare Council,1965 (in Japanese)

全国社会福祉協議会「保育の友」編集部：「保育所保育指針」全文とその 見方，全国社会福祉協議会，1965

13) Ministry of Health and Welfare: Hoikusyohoikushishin (Childcare Guidelines for Daycare Facilities), Flabel kan, 1990.4(in Japanese) 厚生省児童家庭局：保育所保育指針，フレーベル館， 1990.4

14) Thelma H., Debby C., Richard M. C. : INFANT/TODDLER ENVIRONMENT RATI NG SCALE, Revised Edition, Reiko U. Trans., Horitsu Bunka Sha, 200 4. 4 (in Japanese)

テルマ ハームス, デビィ クレア, リチャード M. クリスフォード:保育環境 評価スケール(2)<乳児版 >, 埋橋玲子訳, 法律文化社, 2004.4

注

注 1) 厚生労働省 : 保育所等関連状況取りまとめ (平成 29 年 4 月 1 日) 参照。 就学前児童の保育所等利用率は $42.4 \%$ であり，3 歳未満児は $35.1 \%, 1 ・ 2$ 歳児においては $45.7 \%$ で，この 10 年間で倍増しているという。

https://www. mhlw. go. jp/content/11907000/000350592.pdf, (2018.10.10 閲覧）

注 2) 参考文献 1)，最終改訂は平成 29 年告示，平成 30 年 4 月 1 日施行。

注 3）厚生労働省 : 改正育児休業・介護休業法のポイント参照。保育所に入 所できない等の理由がある場合，満 2 歳まで育巟休業を取得することが可 能となった。このため, 満 1 歳児を過ぎてからの保育所利用が今後増える ことが推察される。

https://www. mhlw. go. jp/file/06-Seisaku jouhou-11900000-Koyoukintouj idoukateikyoku/291001_ikukaiho-kaisei-point.pdf (参照 2018-10-10)

注 4）参考文献 2), pp. 116，参考文献 3),pp. 81, 参考文献 4),pp. 147 を参照に 作成。

注 5) 参考文献 14), pp. 64-65, 活動の移行時間に関する直接的な評定項目は無 いが、日課の項目において一部活動の移行について触れている。子どもが 活動の移行場面で, 何もせず待たされることは良いとされていないことが 読み取れる。

注 6) C 園施設長へのヒアリングより，他の 3 園と同様にクラス単位での活動 を基本とし「集団での育ちを大切にしている」こと，また排泄・手洗い・ 外遊び準備等の場面において, 小グループに分かれて保育を行う理由とし て，(1)特定の場所に利用が集中し，子どもの待ち時間が長くなることを防 ぐ，(2）(一度に 27 名の子どもをみるより)子ども一人ひとりに職員の目が 行き届きやすくなる，(3) 月齢の近い児毎に活動を分けることで，手のかか る低月齢児により手をかけや寸くなる, との回答を得ている。

注 7）平均值(分) で, A 園 50.0, B 園 45.8, C 園 58.5, D 園 58.8 である。

注 8) A 園では同様の姿が 2 例 ( $\mathrm{a} 1, \mathrm{a} 2)$ 見られた。D 園では待たずに座って靴 を履き始められる状況下で, 特定の览Xが, 靴を履かずに土間を歩くまたは 室内側に逃げる姿の 3 例 $(\mathrm{d} 1, \mathrm{~d} 3, \mathrm{~d} 4)$ が見られた。なお B 園及び C 園では, このような児の姿は観察されていない。

注 9) 時間が確認された事例から算出した平均值(分)である。A 園(平均 8.0 分) :6(a1), 7 (a2), 11 (a3), B 園 (平均 5.3 分) :6(b2), 5(b3), 5 (b5), C 園 (平 均 5.0 分): 6 (c1, (1)組), 4 (c2, (1)組), 6 (c2, (2)組), 3 (c3, (3)組), 6 (c4, (1) 組), 4 (c5, (1)組), 6 (c6, (1)(2)組), D 園 (平均 3.3 分) :4 (d1) , 3 (d2), 3 (d3), 3 (d4)。

注 10) 子どもが布団のまわりを走り回る等の姿が観察された事例は、A 園 （a1, a2, a3, a4, a6)，B 園 (b3, b4)，C 園（c5）, D 園 (d1, d3, d4, d5) である。

注 11）注 10) 参照。午睡空間の落ち着きを阻害するものとして, 着替えや排泄 の順番が待てずに，うろうろし，遊び始める子どもの他，それを注意する保 育者の声, 着替えや排泄に伴う保育者と子どもの会話が含まれる。

注 12）児童福祉施設の設備及び運営に関する基準（昭和 23 年厚生省令第 63 号, 以下国基準)において, 保育所の職員配置基準や保育室面積が定められ ているが, 法改正に伴い平成 24 年 4 月から, 国基準を下回らない範囲で, 都 道府県が条例で基準を定めることとなった。1 歳児の場合, 職員配置基準(国 基準）は, $6: 1$ (子ども 6 人に対して保育士 1 名）で, B 園（埼玉県）及び D 園（千葉県）はこれに該当する。一方 $\mathrm{A} ・ \mathrm{C}$ 園（東京都）の職員配置基準は 5：1 であり, C 園では計 6 名の保育士が配置されている。なお A 園は保育 士数 4 名のうち, クラス担任は 3 名 (Table. 1)で, もう 1 名はフリー(保育士) で対応しており, 職員配置基準は満たしている。また保育室の面積基準（1 歳児）は, 条例に基づいて,いずれも $3.3 \mathrm{~m}^{2} /$ 人である。

注 13）注 12）参照。1 歳児クラス 18 名の場合,保育士数は最低 3 名（国基準） となり,補助職員 1 名が更に必要となる。 


\section{A STUDY ON THE CLASS SIZE AND THE NURSERY SPACE COMPOSITION}

Focusing on the activity scene of one-year-old child class

\section{Megumi HASEGAWA *1 and Mariko SADAYUKI *2}

\footnotetext{
${ }^{* 1}$ Grad. Student, Graduate School of Human Life Science, Division of Living environment, Japan Women’s University, M.Eng. Senior Researcher, Misawa Homes Institute of Research and Development Co., Ltd.

${ }^{*}$ Prof., Dept. of Housing and Architecture, Japan Women's University, Dr.Eng.
}

In recent times, there has been an increasing demand for childcare, especially for infants below 3 years of age, in Japan. This has led to a massive expansion of licensed nursery schools. Nursery facilities are required to have at least the minimum capacity size and area per child as prescribed by the guidelines. However, guidelines for appropriate group size and space composition in nursery rooms for one-year-olds have not been mentioned so far.

The purpose of this research is to propose a design method for nursery rooms of one-year-olds that suits the group size, from the perspective of it being "an environment that allows children opportunities to do things independently."

This proposed design considers the following points: 1) Children are not disturbed by the activities of one another. 2) Children's waiting time is short. 3) Childminders should understand that children mostly want to do things by themselves and in their own pace.

We conducted observation studies in four facilities located in areas around Tokyo. Two of the four have a capacity of 20 or more children in the one-year-old class, the rest have about 10 to 15 . They are private licensed nursery schools managed by the same operator. We examined how group size affects the daily program, childcare methods, and the way of using the nursery rooms.

A comparison analysis is conducted between the group size of "about 10 to 15 " and "more than 20," from the perspective of whether it creates an environment that allows children opportunities to do things independently."

The results of this study can be summarized as follows: 1) The duration from lunch to napping and children's waiting time is longer in the case of the nursery having "20 or more" one-year-olds. 2) From the behavior of the children and childminders during the transition from lunch to napping, the layout of the eating space, changing space, restroom, and napping space are classified into "HUB type" and "SLIDE type."

In the "HUB type," they go to and from the lunch room and restroom centering on the room for napping. Compared with the "SLIDE type", childminders can easily handle multiple actions at the same time in one place. However, multiple actions are carried out at the same time in the room for napping, and hence, it is difficult to secure quietness and calm.

In the "SLIDE type," slides are moved into different positions in the room for each activity. Since there is only one kind of action performed in the space, children can spend their time in a calmer environment. Finally, if the group size is "20 or more," it is preferable to make rooms using slides as partitioning so that these can be moved around the room for each activity, in the transition from lunch to napping. Furthermore, we found that dividing a room with movable wall partitions offers childminders some options, as follows: 1) They can temporarily organize small groups according to the children's developmental stage for each activity. 2) In a calm atmosphere, children have more opportunities to do things independently. 3) Making a buffer-like space, they can easily avoid congestion in a specific area and smoothly shift to the next activity with a time lag. 